\title{
COMMENTS
}

\section{UNINCORPORATED ASSOCIATIONS: DIVERSITY JURISDICTION AND THE ALI PROPOSAL}

$\mathrm{U}$ NDER section 1332 (a) of the Judicial Code, federal district courts have original jurisdiction of civil actions between "citizens of different states." 1 This provision requires complete diversity of citizenship between all original parties opposed in interest. ${ }^{2}$ Once diversity jurisdiction has been established, section 1391 (a) of the Judicial Code states that venue is proper in the judicial districts where all the plaintiffs or all the defendants reside. ${ }^{3}$ Section 1332 (c) explicitly provides that corporations shall be deemed citizens of both their state of incorporation and state of principal place of business; corporate residence for venue purposes is expressly provided for in section 1391 (c). The absence of an exclusive constitutional or statutory definition of citizens ${ }^{4}$ or residents, however, has resulted in decisional conflict regarding the diversity and venue requirements for unincorporated associations. ${ }^{5}$ Accordingly, as part of a study of federal and state jurisdiction, the American Law Institute has recommended legislation clarifying the status of unincorporated associations for diversity and venue purposes. Some may fear, however, that this change will produce the undesirable result of increasing the caseload in federal district courts.

128 U.S.C. $\$ 1332$ (a) (1958). The matter in controversy must exceed the sum or value of $\$ 10,000$, exclusive of interest and costs.

2 Thus, all plaintiffs must be citizens of different states than each and every defendant. Strawbridge v. Curtiss, 7 U.S. (3 Cranch) 267 (1806). Complete diversity, however, is not required for third-party practice. See, e.g., lA BARRoN \& Holmofr, Federal Practice and Procedure \$ 424 (Wright ed. 1960).

828 U.S.C. $\$ 1391$ (a) (1958).

- Diversity jurisdiction is predicted upon the constitutional grant of judicial power to controversies "between Citizens of different States." U.S. CoNST. art. III, § 2. "Persons born or naturalized" in the United States are citizens of the state in which they reside. U.S. Const. amend. XIV, $\S 1$. The fourteenth amendment is not an exclusive definition of "citizens" on its face, and legislation has conferred citizenship beyond the limits of that amendment. See Anderson v. A. \& W. Tractor Prods., Inc., 181 F. Supp. 90 (S.D. Ill. 1960); Harlan v. Pennsylvania R.R., 180 F. Supp. 725 (W.D. Pa. 1960 ). Both cases rejected arguments that 28 U.S.C. $\$ 1332$ (c) was unconstitutional. See Wright, Federal CourTs 77 (1963).

"In this comment the terms "unincorporated association" and "association" refer to legal forms such as joint ventures, joint stock associations and business trusts, as well as partnerships and limited partnerships. 


\section{Diversity Jurisdiction: Present I A W}

Historically, a corporation was the only form of business association viewed as an entity separate and distinct from its individual members. ${ }^{B}$ At common law, therefore, unincorporated associations could neither sue nor be sued as an entity. ${ }^{7}$ This denial of juridical capacity to such associations prompted federal courts to hold that unincorporated associations possessed no citizenship apart from that of their individual members. ${ }^{8}$ Although the modern tendency in many states has been to confer capacity to sue and be sued as entities upon unincorporated associations, ${ }^{\theta}$ citizenship separate and distinct from its members for diversity purposes has been denied in virtually all cases. ${ }^{10}$ Thus, with the exception of the class action procedure, ${ }^{11}$

- Originally, the United States Supreme Court held that a corporation could not be a citizen. Hope Ins. Co. v. Boardman, 9 U.S. (5 Cranch) 57 (1809). However, the Court later held that a corporation is a citizen of the state of its incorporation for the purpose of suing and being sued. Louisville, C. \& C.R.R. v. Letson, 43 U.S. (3 How.) 497,555 (1844). The governing common law rule was finally settled in 1854, when the Court established the irrebuttable presumption that for purposes of diversity jurisdiction the stockholders of a corporation are citizens of the state of its incorpora. tion. Marshall v. Baltimore \& O.R.R., 57 U.S. (16 How.) 314, 328 (1854). In 1958, Congress enacted specific legislation decming corporations citizens of their state of incorporation and state of principal place of business. 28 U.S.C. $\$ 1332$ (c) (1958). See note 97 infra.

7 United Mine Workers v. Coronado Coal Co., 259 U.S. 344, 385 (1922); 2 TELLER, Labor Disputes and Collective Bargaining $\$ \$ 462,467$ (1940); Cohn, Problems In Establishing Federal Jurisdiction Over An Unincorporated Labor Union, 47 GEO. L.J. 491, 492 (1959); Forkosch, The Legal Status and Suability of Labor Organizations, 28 TeMrP. L.Q. 1, 2.5 (1954).

O Cohn, supra note 7, at 509; see, e.g., Great Southern Fire Proof Hotel Co. v. Jones, 177 U.S. 449 (1900); Chapman v. Barney, 129 U.S. 677 (1889).

Unincorporated associations are permitted to sue and be sued as an entity in federal courts where jurisdiction is based upon a question of substantive fcderal law. FED. R. Crv. P. 17b. The capacity to sue and be sued as an entity for diversity purposes is determined by state law. FED. R. Civ. P. 17b; Cohn, supra note 7, at 493.

- Statutes in most jurisdictions render unincorporated associations capable of sting or being sued. Comment, 66 YALE L.J. 712, 714 (1957). Sce text accompanying notes 154-64 infra. These statutes are considered in Forkosch, supra note 7.

See also United Mine Workers of America v. Coronado Coal Co., 259 U.S. 344, 391 (1922), holding that an unincorporated labor union could suc or be sued as an entity in the federal courts. The case was originally construed to make the change a procedural matter, applicable in both diversity and federal question cases. Sce Hansel v. Purnell, I F.2d 266, 269 (6th Cir. 1924). But see Russell v. Central Labor Union, 1 F.2d 412 (E.D. Ill. 1924). A later Supreme Court decision made it clear that it did not pertain to diversity jurisdiction. Moffat Tunnel League v. United States, 289 U.S. 113 (1933).

${ }^{10}$ E.g., R. H. Bouligny, Inc. v. United Steelworkers of America, 336 F.2d 160 (4th Cir. 1964), cert. granted, 879 U.S. 958 (1965) (No. 652); Hanson v. Chicago, B. \&. Q.R.R., 282 F.2d 758 (7th Cir. 1960), cert. denied, 365 U.S. 850 (1961); Brocki v. American Express Co.. 279 F.2d 785 (6th Cir. 1960); Stcin v. American Fed'n of Musicians, 188 F Supp. 99 (M.D. Tenn. 1960). Contra, cases cited note 24 infra.

2 FED. R CIV P 23. 
diversity jurisdiction is available in most district courts only when the citizenship of each and every association member differs from that of the opposing parties. ${ }^{12}$

\section{Class Actions}

Under Rule 23 of the Federal Rules of Civil Procedure, if a class is so numerous as to make it impractical to join all members, one or more of the class insuring adequate representation of all may under certain circumstances sue or be sued on behalf of all.13 This procedure enables diversity jurisdiction to be created by or against unincorporated associations by naming as parties only those members whose citizenship differs from that of the adversary litigants. ${ }^{14}$ The fact that an unincorporated association cannot sue or be sued as an entity under controlling state law does not preclude use of the class action device by or against its representative members. ${ }^{\mathbf{1 5}}$

Although the class action procedure is of some efficacy, it has been aptly characterized as "a tortuous if not irrational route to diversity jurisdiction." 16 Proof of the propriety of the designated class, ${ }^{17}$ the adequacy of representation afforded by the named parties, ${ }^{18}$ and the impracticality of joining all members of the class ${ }^{19}$ are all prerequisites to the utilization of a federal class action. Moreover, the effect of a money judgment entered against a class may vary

${ }^{12}$ Compare cases cited note 10 supra, with cases cited note 24 infra.

${ }^{18}$ The right involved must be either: joint in the sense that all members of the class succeed to the claim; or several when the claims to be adjudicated affect specitic property; or several and there is a common question of law or fact affecting the several rights and a common relief is sought. FED. R. Crv. P. 23a-c.

14 3 Moore, Federal Practice If 23.08, at 3435-36 (2d ed. 1964) [hereinafter cited as MoorE]. See Calagaz v. Calhoon, 309 F.2d 248, 251-53 (5th Cir. 1962) (class action sanctioned to prevent defendant-association from defeating diversity jurisdiction).

${ }^{15}$ Benz v. Compania Naviera Hidalgo, S.A., 233 F.2d 62, 67-68 (9th Cir.), cert. denied, 352 U.S. 890 (1956), aff'd, 353 U.S. 138 (1957); Montgomery Ward \& Co. v. Langer, 168 F.2d 182, 186-87 (8th Cir. 1948). Contra, Underwood v. Maloney, 256 F.2d 334, 342 (3d Cir.), cert. denied, 358 U.S. 864 (1958).

${ }^{10}$ Comment, 68 Yale L.J. 1182, 1196 (1959).

${ }^{17}$ See Tunstall v. Brotherhood of Locomotive Firemen, 148 F.2d 403, 404-05 (4th Cir. 1945); Citizens Banking Co. v. Monticello State Bank, 143 F.2d 261, 264 (8th Cir. 1944); American Newspaper Guild v. Mackinnon, 108 F. Supp. 312 (D. Utah 1952). For problems inherent in this prerequisite see Cohn, supra note 7, at 504-06.

${ }^{18}$ See Hansberry v. Lee, 311 U.S. 32, $42-46$ (1940); Brotherhood of Locomotive Firemen v. Graham, 175 F.2d 802, 806-07 (D.C. Cir. 1948), rev'd on other grounds, 338 U.S. 232 (1949); Knowles v War Damage Corp., 171 F.2d 15, 18 (D.C. Cir. 1948), cert. denied, 336 U.S. 914 (1949); Cohn, supra note 7, at 506-07.

"O See Kainz v. Anheuser-Busch, Inc., 194 F.2d 737, 740 (7th Cir.), cert denied, 344 L.S. 820 (1952). Rank v. United States, 142 F. Supp. 1. 157 (S.D. Cal. 1956). 
from state to state. ${ }^{20}$ The Third Circuit has complicated matters further by holding that the class action procedure is unavailable where state law forbids "class suits" against unincorporated associations. ${ }^{21}$

As an alternative means of diversity access to a federal forum, the class action device appears unrelated to the more fundamental issue of whether unincorporated associations should be entitled to citizenship as an entity for diversity purposes. ${ }^{22}$ The procedure is manipulable and cumbersome, and the existence of diversity jurisdiction in a class action is normally fortuitous.

\section{Complete Diversity-The Entity as a "Citizen"}

In recent years, therefore, some commentators ${ }^{23}$ and courts ${ }^{24}$ have departed from traditional doctrine and urged that multistate associations should be accorded a single citizenship as an entity for diversity purposes. Illustrative of the present judicial controversy are two recent federal court of appeals decisions. In Mason v. Ameri-

${ }^{30}$ See Comment, supra note 16, at 1193-94 \& n.55.

${ }^{11}$ Underwood v. Maloney, 256 F.2d 334 (3d Cir.), cert. denied, 358 U.S. 864 (1958). There a local union, by its president and some of its members, sued in a Pennsylvania federal district court to enjoin enforcement of an order of the international union with which the local was affiliated. Since Pennsylvania law prohibited class suits against unincorporated associations, the court of appeals dismissed the action for lack of jurisdiction, reasoning that state law determines the capacity to be sued in diversity cases.

${ }^{22}$ It is submitted that the policies underlying diversity jurisdiction should be taken into account before permitting class actions by or against unincorporated associations. See text accompanying notes 114-116 infra.

${ }^{28}$ See, e.g, Hart \& Wechsler, The Federal Courts ANd the Federal System 917-18 (1953); 3 MOORE I 17.25, at 1413-14; Cohn, supra note 7, at 510; Comment, supra note 9; Note, 83 Colum. L. Rev. 540, 541 (1983).

"See Mason v. American Express Co., 894 F.2d 392 (2d Cir. 1964); Ex parte Edel. stein, 30 F.2d 636, 638-40 (2d Cir. 1929) (dissenting opinion), cert. denied, 279 U.S. 851 (1929); Jacques Krijn En Zoon v. Schrijver, 151 F. Supp. 955, 957 (S.D.N.Y. 1957); Remington's Dairy v. Rutland Ry., 15 F.R.D. 488 (D. Vt. 1954).

In Van Sant v. American Express Co., 169 F.2d 355 (3d Cir. 1948), a joint stock company was treated as a citizen of the state of its organization, and the court held that the company could be sued as an entity. The significance of the holding in relation to the diversity question is not clear since the court did not squarely meet the problem. The objection that it had no jurisdiction because a joint stock company has no citizenship apart from that of its individual members was rejected as being untimely. The case has been criticized for failing to distingnish between treatment of the association as an entity for purposes of diversity jurisdiction and for capacity for suit. Swan v. First Church of Christ, 225 F.2d 745, 748 (9th Cir. 1955); Mason v. American Express Co., 224 F. Supp 288, 294 (S.D.N.Y. 1963), rev'd, 334 F.2d 392 (2d Cir. 1964). It is arguable that even if the Van Sant court had recognized the problem, it would have arrived at the same result since it stated by way of dictum that the rule that only a corporation is an entity for diversity purposes is "beginning to show signs of being outmoded." 169 F.2d at 372 n.7. 
can Express Co. ${ }^{25}$ the Second Circuit held that a joint stock company was a citizen of the state of its principal place of business for purposes of diversity jurisdiction. One month later, the Fourth Circuit in R. H. Bouligny, Inc. v. United Steelworkers of America ${ }^{26}$ expressly disagreed with the Mason decision ${ }^{27}$ in holding that a labor union has no citizenship for diversity purposes apart from that of its individual members. The divergent results in Mason and Bouligny are attributable, inter alia, to differing interpretations of the Supreme Court's decisions in Chapman v. Barney ${ }^{28}$ and Puerto Rico v. Russell \& $C o . .^{29}$

Although a joint stock company in Chapman was authorized by state law to sue in the name of its president, the Court held that it could not be a citizen of that state for diversity purposes unless it was a corporation. ${ }^{30}$ At the turn of the century, the Court reaffirmed that decision and held that limited partnerships "having some of the characteristics of a corporation" could not be classified as a corporation for diversity of citizenship. ${ }^{31}$

The question in Russell was whether a Puerto Rican Sociedad en Commandita, the civil law counterpart of a limited partnership, could remove a suit brought against it to the federal district court. ${ }^{32}$ The district court for Puerto Rico had been given jurisdiction by special legislation over "all controversies where all of the parties on either side ... are citizens ... of a State, Territory, or District of the United States not domiciled in Puerto Rico...."33 Although the Sociedad was organized under Puerto Rican law, none of its members were Puerto Rican domiciliaries.34 The Supreme Court, nevertheless, denied jurisdiction to the district court by accepting the plaintiff's contention that the domicile of the association, rather

26 334 F.2d 392 (2d Cir. 1964).

${ }^{26} 336$ F.2d 160 (4th Cir. 1964), cert. granted, 379 U.S. 958 (1965) (No. 652).

${ }^{27}$ Id. at 163 n.3.

${ }^{28} 129$ U.S. 677 (1889). This case was twice reaffirmed by the Court within fifteen years of its decision. Thomas v. Board of Trustees, 195 U.S. 207, 211 (1904); Great Southern Fire Proof Hotel Co. v. Jones, 177 U.S. 449, 454-55 (1900).

20288 U.S. 476 (1933).

so 129 U.S. at 682 .

s1 Great Southern Fire Proof Hotel Co. v. Jones, 177 U.S. 449, 457 (1900).

${ }^{82}$ Suit was instituted dgainst the defendant in the Insular Court of Puerto Rico. 288 ''S. at 477.

${ }^{83}$ Organic Act of Puerto Rico, ch. 145, § 41, 39 Stat. 965-66 (1917), as amended, 48 U.S.C. \& 863 (1958).

B4 288 U.S. at 477. 
than of its individual members, ${ }^{35}$ should determine citizenship for purposes of federal jurisdiction. ${ }^{36}$ Comparing the characteristics of a Sociedad under Puerto Rican law ${ }^{37}$ to the common characteristics of a corporation, ${ }^{38}$ the Supreme Court found the former to have a "personality ... so complete... that we see no adequate reason for holding that the sociedad has a different status for purposes of federal jurisdiction than a corporation ...."39

The Bouligny court felt that the Russell case had no significance beyond its narrow holding that the Sociedad's individual members were not "parties" within the special jurisdictional statute. The Russell determination that an unincorporated association sharing common characteristics with a corporation was a citizen was held inapplicable for purposes of diversity jurisdiction. ${ }^{40}$ Thus, under the authority of Chapman, unincorporated associations cannot obtain citizenship as an entity. ${ }^{41}$

The Second Circuit in Mason, however, adopted the broad language in Russell to mean that for jurisdictional purposes generally, an unincorporated association may possess citizenship apart from that of its individual members if its structural characteristics are such as to vitiate any meaningful distinction between it and a

s5 "Admittedly, if the individual members of the sociedad are 'parties' within the meaning of the Organic Act,... the suit is one within the jurisdiction of the District Court because of their nonresidence, diversity of citizenship being unnecessary." Id. at 478 .

so Id. at 479.

s7 The Sociedad was found to be similar to a corporation in that under Puerto Rican law: its members were not entitled to intervene as parties defendant; it was treated as an entity for purposes of suit; it could own property and transact business in its own name; it was created by articles of association which were public records; its duration was not necessarily affected by death of individual members; the power to legally bind the Sociedad could be vested in a limited number of the members; its creditors were preferred regarding its assets over creditors of the members. Id. at 481 .

${ }^{88}$ At that time, corporations could obtain diversity jurisdiction despite the absence of statute. See note 6 supra.

${ }^{80} 288$ U.S. at 482 . The fact that the individual members of the Sociedad were unhimitedly liable for its obligations was held irrelevant. Id. at 481.

'Diversity of citizenship could not be obtained in Russell because the plaintiff, the government of a United States territory, did not qualify. Thus Bouligny carefully noted that this issue was not before the Court. 336 F.2d at 163.

"1 Bouligny also relied upon Supreme Court language to the effect that the rule extending citizenship to a corporation for diversity purposes "must not be extended." Id. at 162, quoting Great Southern Fire Proof Hotel Co. v. Jones, 177 U.S. 449, 457 (1900). The two cases are distinguishable, however, on the ground that the limited partnership in Great Southern was seeking citizenship as a corporation, whereas it was urged in Bouligny that the limited partnership was entitled to citizenship in its own right as an unincorporated business entity. 
corporation.12 The apparently contrary authority of Chapman, according to the Second Circuit, was by implication limited in Russell to mean that capacity to sue is insufficient, in and of itself, to afford a complete and separate personality for purposes of citizenship. ${ }^{43}$

Without regard to policy factors, it would appear that Mason's construction of Russell is technically accurate. Although Bouligny was correct in emphasizing that diversity of jurisdiction was not at issue in Russell, ${ }^{44}$ the Supreme Court had there stated that an unincorporated association may be treated as a citizen separate and clistinct from its members "for purposes of federal jurisdiction." 45 Moreover, the same phrase "citizens of a State" was employed by Congress in section 1332 and the special jurisdictional statute in Russell; thus, it seems reasonable to presume that where two statutes employ the same term for creating jurisdiction in federal courts, the term is generic for definitional purposes. ${ }^{46}$

The court in Bouligny also argued that even if Russell could be interpreted as a departure from the traditional view, it was overruled for diversity purposes by the 1958 amendment to section 1332.47 Prior to 1958, when the jurisdictional statute referred only to "citizens," 48 the courts had ruled that a corporation satisfied the

"The Court stated that Russell represented a clear departure from the "mechanical rule" of Chapman v. Barney. 334 F.2d at 398. It argued that the basic issue in Russcll was whether the Sociedad was to be treated as an entity, and, therefore, as a citizen of Puerto Rico.

"3 According to the Russell Court, Chapman stands for the proposition that "status as a unit for purposes of suit alone, as in the case of a joint stock company, ... has been deemed a legal personality too incomplete; what was a juridical entity for only a few [purposes], was not easily to be treated as if it were a single citizen." 288 U.S. at 480 . According to Mason, this aspect of the Russell opinion expressly limits Chapman, thus leaving courts free to characterize unincorporated associations as entities or nonentities for purposes of federal jurisdiction on an ad hoc basis. 334 F.2d at 399. The guidelines for such determinations were established in Russell. See note 37 supra.

"See note 40 supra.

'Sce text accompanying note 39 supra.

'The Bouligny court appeared to discount Russell's significance on the basis that the jurisdiction of the District Court for Puerto Rico differs from that of the normal Article III court. Cf. Munoz v. Porto Rico Ry. Light \& Power Co., 83 F.2d 262, 264 (1st Cir. 1936), cert. denied, 298 U.S. 689 (1936). However, this difference does not alter the essence of the Russell decision, since the test of the existence of jurisdiction in terms of "citizens of a State" is identical under both statutes.

: The statute was amended to state that a corporation "shall be deemed a cutizen uf anv State by which it has been inculporated and of the State where it has its principal place of busmess $\quad * 28$ L S.C. $\$ 1332$ (c) (1958). added by 72 \$1at. 415 (1958).

${ }^{4}$ See 62 Stat 930 (1948, 28 l $>$ ( \$ 1332 ; 1952) 
requirement of complete diversity via the conclusive presumption that all its stockholders were citizens of the state of incorporation.49 Reasoning that congressional inclusion in 1958 of a special provision applicable to corporations signified abandonment of this ancient fiction, the Bouligny court opposed resurrection and extension of the fiction to confer citizenship on unincorporated enterprises.50 Moreover, it asserted that unincorporated associations cannot be equated with corporations in that they are incapable of the dual citizenship amended section 1332 confers on the latter. ${ }^{51}$

Nevertheless, the legislative history of the 1958 amendment indicates no congressional purpose to preclude categorization of business entities other than corporations as citizens for purposes of diversity jurisdiction. The amended provision embodies the same policy that originally motivated judicial employment of a fiction to justify treatment of a corporation as a citizen: that actions by or against a unitary business entity should not be precluded from access to an impartial forum by the fortuitous identity of citizenship between one or more of its shareholders and its litigative adversary. ${ }^{62}$

In view of the desire of many commentators to limit the scope of federal diversity jurisdiction ${ }^{53}$ and the fact that Congress did attempt some circumscription thereof in $1958,{ }^{54}$ the most persuasive justification for the Bouligny result is the court's statement that any change in the traditional treatment of unincorporated associations should be left to Congress. ${ }^{55}$ Other courts seem to have predicated their holdings on the advisability of a legislative rather than a judicial solution. ${ }^{56}$ Perhaps a counter to this argument is the fact that federal diversity jurisdiction is a constitutional grant, ${ }^{57}$ and the question of citizenship can be characterized as one of constitutional construction..$^{58}$ Absent congressional specificity, this leaves

\footnotetext{
See note 6 supra.

80336 F.2d at 163-64.

82 Id. at 164.

32 See Marshall v. Baltimore \& O.R.R., 57 U.S. (16 How.) 314, 325.29 (1854);

McGovney, A Supreme Court Fiction, 56 HARv. L. REv. 858 (1943).

${ }^{8}$ See authorities cited note 193 infra.

od See statute cited note 47 supra; S. REP. No. 1830, 85th Cong., 2d Sess. 8 (1958).

s8 336 F.2d at $164 \&$ n.4.

so See Brocki v. American Express Co., 279 F.2d 785, 788 (6th Cir. 1960); Stein v. American Fed'n of Musicians, 188 F. Supp. 99, 101 (M.D. Tenn. 1960).

87 "The judicial Power shall extend to all Cases... between Citizens of different States ...." U.S. ConsT. art. III, § 2.

${ }^{88}$ See Mason v. American Express Co., 224 F. Supp. 288, 295 (S.D.N.Y. 1963), rev'd, 334 F.2d 392 (2d Cir. 1964); Stein v. American Fed'n of Musicians, 183 F. Supp. 99, 101
} 
the federal courts free to determine whether unincorporated associations shall be deemed citizens for diversity purposes. ${ }^{59}$ Congress, of course, remains free to explicitly restrict or modify any judicial extensions which it deems unwise. ${ }^{80}$

Widespread adoption of the Mason approach, on the other hand, would raise several significant problems. Arguably, the Russell opinion provides guidelines for determining when an association possesses sufficient entity characteristics to be deemed a citizen, ${ }^{\text {b1 }}$ but it did not specify whether all those standards were necessary characteristics. Thus, associations in several states are precluded from suing or being sued as an entity; ${ }^{62}$ many partnership agreements are not public records; nor may the power to bind a partnership be vested in a limited number of partners; ${ }^{63}$ the duration of a partnership is normally affected by the death of an individual partner. ${ }^{64}$ The use of these and other standards enumerated in Russell ${ }^{64 a}$ may determine when an association possesses entityattributes similar to a corporation, but they do not reflect a consistent policy for determining those cases in which a business enterprise should be entitled to a federal forum.

The necessity of ad hoc determinations under the Russell standards may also exact too great a price in terms of judicial time and effort merely for purposes of resolving the preliminary question of jurisdiction. State law governing the rights and privileges of various forms of unincorporated associations may be obscure; ${ }^{65}$ and if a multistate association is involved, the absence of a convenient rule of thumb as to controlling state law may present delicate choice of law questions. It is also uncertain whether a judicial determina-

(M.D. Tenn. 1960). See also National Mut. Ins. Co. v. Tidewater Transfer Co., 337 U.S. 582, 604, 626, 646 (1949) (concurring and dissenting opinions), where six members of the Supreme Court felt that the term "State" in both the constitutional grant and the statute could be interpreted to include the District of Columbia for purposes of establishing diversity of citizenship.

${ }^{\circ D}$ For the view that this determination is a question for the Supreme Court, see Arbuthnot v. State Auto. Ins. Ass'n, 264 F.2d 260, 262 (I0th Cir. 1959).

${ }^{\circ}$ See Burford v. Sun Oil Co., 319 U.S. 315, 344-45 (1943) (Frankfurter, J., dissenting) (Congress, not the Court, has discretion to restrict diversity jurisdiction).

ox See notes $37 \& 39$ supra.

-2 See cases cited notes $154-55$ infra. See also text accompanying notes 159.64 infra, indicating that juridical capacity is not clear under the law of many states.

os See UNIFORM PARTNERSHIP Act $\$ 9$ (1).

ot See UNIFORM PARTNERSHIP ACT $\$ 31$ (4).

- See note 37 supra.

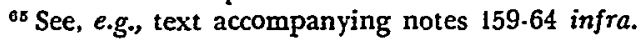


tion of citizenship for diversity purposes would carry res judicata consequences when the association sues or is sued again. Mason and Bouligny have left us with the paradox that some but not all unincorporated associations are entitled to qualify as citizens in some but not all judicial districts. A Supreme Court or legislative resolution is clearly appropriate.

\section{Venue}

Under present law unincorporated associations whose members' citizenship does not preclude diversity jurisdiction may still be barred from federal court by the absence of proper venue. ${ }^{60}$ Ostensibly, the purpose of venue limitations is to define a convenient place of trial, ${ }^{67}$ and the failure of a party to object to improper venue constitutes waiver of the limitation. ${ }^{68}$ The general requirement is that venue in diversity cases shall be laid in the judicial district where all plaintiffs or all defendants reside, 99 but there are two broad exceptions to this rule. Section 1391 (c) of the Judicial Code defines corporate venue as any judicial district in which the corporation is either incorporated, doing business, or licensed to do business, ${ }^{70}$ while section 1391 (f) permits automobile

See, e.g., 1 MOORE \ 0.141 [2-6], at 1412-13, q 0.142 [3], at 1478. The provisions of

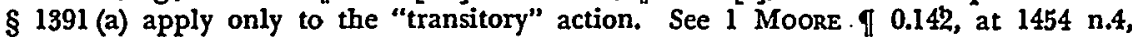
1456.68 .

${ }^{\text {or }}$ Olberding v. Illinois Central Ry., 346 U.S. 838, 340 (1953); Nierbo v. Bethlehem Shipping Corp., 308 U.S. 165, $167-68$ (1939). The provisions of 28 U.S.C. $\$ 1404$ (a), relating to venue transfer, are also partially keyed to convenience. See 1 Moore I 0.145 [3-1], at 1757-58.

${ }^{8} 28$ U.S.C. $\$ 1404$ (b). This enactment was merely declaratory of existing law. See Reviser's Notes, 28 U.S.C. $\$ 1404$ (b); cases cited 1 MOORE II 0.146 [6], at 1911 n.3.

28 U.S.C. $\$ 1391$ (a) (1958). Applied to natural persons, residence means domicile in this context. See cases cited 1 MOORE $\mathbb{0 . 1 4 2}$ [5-2], at 1483 n.l. In regard to venue after removal from state to federal court, see Polizzi v. Cowles Magazines, 345 U.S. 663 (1953) (venue provisions do not generally relate to removed actions). Compare Craft v. Murphy, 156 F. Supp. 486 (M.D. Ala. 1957), with Fawick Corp. v. Alfa Export Corp., 135 F. Supp. 108 (S.D.N.Y. 1955) (effect of new defendants after removal).

${ }^{70} 28$ U.S.C. $\S 1391$ (c) (1958). The absence of geographic hardship justifies broad corporate venue. 1 MOORE I 0.140 [1-1], at 1318. Where hardship is present, transfer under the provisions of 28 U.S.C. $\$ 1404$ (a) may be possible.

However, where applicable, special venue provisions preempt $\$ 1391$ (c). Fourco Glass Co. v. Transmirra Prods. Corp., 853 U.S. 222 (1957). But see Connolly v. Farrell Lines Inc., 268 F.2d 653, 657 (lst Cir.), cert. denied, 361 U.S. 902 (1959); BarberGreene Co. v. Blaw-Knox Co., 239 F.2d 774 (6th Cir. 1957). As to special venue in general, see 1 MOORE If 0.144 [1]-[17], at 1601-85.

Whether a corporate plaintiff may invoke $\$ 1391$ (c) is uncertain. See cases cited id. at 1502 n.50. 
"tort claims" to be sued upon "in the judicial district wherein the act or omission complained of occurred."'il

None of the present venue provisions focuses explicitly on unincorporated associations, ${ }^{\text {ia }}$ and judicial approaches to the problem of association venue have followed four divergent courses. Under the majority view, which conforms to the traditional treatment of unincorporated associations for diversity of citizenship, it is necessary to look to the residence of each and every association member. ${ }^{72}$ Thus, there will be no association-plaintiff venue if members reside in different states, ${ }^{\mathbf{7 3}}$ or even in different judicial districts within the same state, ${ }^{74}$ and no association-defendant venue if members reside in different states. ${ }^{75}$ Other courts afford an association a residence at its principal place of business if under the applicable state law the association is clothed with sufficient entity-attributes. ${ }^{78} \mathrm{~A}$ variant of this is to lay venue in the district wherein the association's principal place of business is located irrespective of local law. ${ }^{77}$ A final approach utilizes section 1391 (c) in order to lay venue in the state where the association is licensed to do or is doing business. ${ }^{75} \mathrm{Re}$ gardless of which approach is used, however, it is clear that actual

i1 28 U.S.C. $\$ 1391$ (f) (Supp. 1964). The underlying rationale of the section is the convenience of witnesses. 1963 U.S. CODE CoNG. \& AD. NEws 1373-74.

${ }^{712}$ It should be noted, however, that $\S 1391$ ( $f$ ) focuses upon the nature and quality of the tortious act rather than the nature of the parties to the suit.

${ }^{72}$ See, e.g., Harris Mfg. Co. v. Williams, 157 F. Supp. 779, 784-85 (WV.D. Ark. 1957). According to Moore, this approach must be used where state law does not permit the association to sue or be sued as an entity. See I MOORE 10.142 [5-4], at 1506 .

${ }^{78} 28$ U.S.C. $\S 1391$ (a). Of course, this fact does not preclude the possibility of proper defendant venuc.

7 WRIGHT, FEDERAL Courts 128 (1963).

${ }^{75} 28$ U.S.C. $\S 1391$ (a) (1958). See Suttle v. Reich Bros. Const. Co., 333 U.S. 163 (1948). This approach has been adopted even though the association has been clothed with the attributes of an entity under state law. See Champion Spark Plug Co. v. Karchmar, 180 F. Supp. 727 (S.D.N.Y. 1960).

Section 1392 (a) provides relief where defendants reside in different districts of the same state. See 1 MOORE If 0.143 [1], at 1555-56.

${ }^{78}$ Koons v. Kaiser, 91 F. Supp. 511 (S.D.N.Y.), mandamus denied, 187 F.2d 1023 (2d Cir. 1950), cert. denied, 340 U.S. 942 (1951); Darby v. Philadelphia Transp. Co., 73 F. Supp. 522 (E.D. Pa. 1947).

"7 Sperry Prods., Inc. v. Association of Am. Railroads, 132 F.2d 408 (2d Cir. 1942), cert. denied, 319 U.S. 744 (1943); cases cited 1 MoORE I 0.142 [5-4], at 1507 n.17.

${ }^{78} 28$ U.S.C. $\S 1391$ (c) (1958). See Eastern Motor Express v. Espenshade, 138 F. Supp. 426, $431-32$ (E.D. Pa. 1936); Portsmouth Baseball Corp. v. Frick, 132 F. Supp. 922 (S.D.N.Y. 1955); cf. American Airlines, Inc. v Airline Pilots Ass'n, 169 F. Supp. 777, 781-82 (S.D.N.Y. 1958). But see Cherico v. Brotherhood of Railroad Trainmen, 167 F. Supp. 635, 637-38 (S.D.X.Y. 1958). Accurding to the Bouligny court. "by no stretch of the process of interpretation can $[\$ 1391$ (c)] . be read as applring to an unincorporated association." 336 F 2d at 164. 
appointment of an agent pursuant to state law to receive service of process constitutes waiver of the right to object to improper venue..$^{78}$

The majority approach is consistent with the traditional theory that an unincorporated association has no entity separate and distinct from its members. As preceding portions have indicated, however, inroads on the aggregate theory have been made for several purposes, ${ }^{80}$ including citizenship for purposes of diversity. It would be anomalous for the Mason court, for example, to confer citizenship as an entity for diversity purposes only to return to the aggregate theory in determining proper venue. Even if a court accepts the result obtained in Bouligny, arguably application of the aggregate theory for venue purposes is unrelated to factors of convenience if defendants are scattered throughout many states. Bouligny, of course, has the practical effect of excluding from diversity jurisdiction many of those cases where members are so scattered.

The difficulty in affording an association a residence apart from that of its members for purposes of section 1391 (a), under the theory that an association may possess entity attributes by state law, is that state law should not govern federal venue. 81 Moreover, attempts to apply section $I 391$ (c) require a tortured interpretation of the word "corporation." 82 For claims arising out of the association's transactions, however, the approach favoring the principal place of business regardless of local law would appear closely related to questions of convenience. Since "residence" for venue purposes

70 Neirbo v. Bethlehem Shipping Corp., 308 U.S. 165, 170-71 (1939). The defendant must have actually appointed the agent, and failure to do so, even in contravention of state law, prevents waiver. See, e.g., Moss v. Atlantic Coast Line R.R., 149 F.2d 701 (2d Cir. 1945). But cf. Knott Corp. v. Furman, 163 F.2d 199, 204.07 (4th Cir.), cert. denied, 332 U.S. 809 (1947). The Neirbo doctrine does not apply to ficticious appointments under non-resident motorists statutes. Olberding v. Illinois Central R.R., 346 U.S. 838 (1953), but the provisions of 28 U.S.C. \& I391 (f) (1964 Supp.) will generally apply to such cases.

One court has held that waiver by appointment of an agent is limited to claims arising within the state. North Butte Mining Co. v. Tripp, 128 F.2d 588 (9th Cir. 1942). However, since state law determines the extent of the waiver, there may be waiver for claims arising outside of the state. See, e.g., Gibson v. United States Lines, 74 F. Supp. 776 (D. Md. I947); Barrett v. National Malleable \& Steel Castings Co., 68 F. Supp. 410, 414-16 (W.D. Pa. 1946).

so See, e.g., cases cited note 24 supra, and text accompanying notes 154.64 infra.

${ }^{81}$ See cases cited 1 MOORE 0.140 [1-8], at 1322 n.6. However, to the extent that state law determines where a corporation is incorporated or requires appointment of an agent for service of process, see note 79 supra.

${ }_{82}$ Nevertheless, the policy justifying corporate venue also applies to unincorporated associations. See American Airlines, Inc. v. Airline Pilots Ass'n, 169 F. Supp. 777, 781-82 (S.D.N.Y. 1958). 
normally follows "citizenship" for diversity purposes, ${ }^{83}$ it is unlikely that Congress or the courts will provide a uniform solution to one problem and not the other.

\section{A Legislative Solution}

\section{The ALI Proposal}

In its "Study of the Division of Jurisdiction Between State and Federal Courts," the American Law Institute has proposed that the Judicial Code be amended to recognize any unincorporated association with juridical capacity under state law as a citizen of the state of its "principal place of business" for purposes of diversity jurisdiction. ${ }^{84}$ Moreover, the Institute proposes that such citizenship should terminate the present practice of creating or avoiding diversity jurisdiction by means of a class action by or against representative association members of selected citizenship. ${ }^{85}$

The ALI proposal states that diversity jurisdiction "presently extends to substantial classes of cases which have no valid justification for being in the national courts and omits some which should have access to the federal forum." 86 Taking its fundamental premise to be that the function of diversity jurisdiction is to insure a "high level of justice" to the out-of-state litigant, the Institute has proposed to deny federal jurisdiction in those cases where a party's involvement with a state is sufficient to eliminate risk of prejudice.87

"With respect to individuals, "domicile" determines citizenship for diversity purposes, see WRIGHT, op. cit. supra note 74, at 74-75, despite the fourteenth amendment's reference to residents; venue is likewise determined by reference to domicile. See note 69 supra. With respect to corporations, citizenship under $\$ 1332$ (c) and venue under $\S 1391$ (c) are both determined by the corporation's principal place of business, although citizenship may also be established by the state of incorporation, and venue may also be proper in any state in which the corporation does business or is licensed to do business. 28 U.S.C. $\S \S 1332$ (c), 1391 (c) (1958). According to Wright, many courts treat citizenship and residence as "one and the same thing" although there is contrary authority as well. WRIGHT, op. cit. supra at 129-30.

8. "A partnership or other unincorporated association capable of suing or being sued in its common name in the State in which an action is brought shall be deemed a citizen of the State or foreign state where it has its principal place of business...." ALI, Study OF THE Division of JuRISDiction Between STATE aNd Federal Courts, § 1301 (b) (2), at 8 (Tent. Draft. No. 2, 1964) [hereinafter cited as ALI Srudy].

${ }_{85}$ Thus, the citizenship defined in $\$ 1301$ (b) (2), see note 84 supra, is "controlling in determining jurisdiction.. whether brought... by or against any person as an agent or representative thereof." ALI STUdy $\$ 1301$ (b) (2), at 8: see Commentary Al.I ST'DY at 61-62.

80 ALI STUdY al 2.

67 Ibid. 
Accordingly, the Institute's 1964 Draft precludes invocation of diversity jurisdiction by any "person," apparently including corporations and unincorporated associations, in any district of the state of which such person is a citizen. ${ }^{88}$ In addition, diversity jurisdiction may not be invoked by a corporation, either originally as a plaintiff or on removal as a defendant, if at the time of suit, or at the time when the acts giving rise to litigation occurred, the corporation has been "locally established" in the forum state for more than two years. ${ }^{89}$ This prohibition applies only to claims related to the activities of that local establishment. ${ }^{00}$ The STudy carefully notes, however, that the "local establishment" provision is not intended to apply to unincorporated associations. ${ }^{91}$ Moreover, although an "individual citizen" with a principal place of business or employment in a state for more than two years is prohibited, in certain cases, from invoking diversity jurisdiction in that state, precludes application of that section to unincorporated associations. ${ }^{93}$

For venue purposes the ALI Draft regards an unincorporated association as a "resident" of the district of its principal place of business. $^{94}$ Furthermore, the Institute proposes to limit venue to the judicial district wherein: (a) a substantial part of the events or omissions giving rise to the particular litigation occurred; or (b) all defendants reside; or (c) any defendant resides, if all defendants

${ }^{8 s}$ ALI STUDY $\S 1802$ (a) at 11 (referring only to "any person," but the reference to natural persons in the Draft is usually phrased as "any individual"); Commentary, ALI STUDY at 67-68 (referring only to citizens and apparently not limiting the provision to natural persons).

The ALI has proposed a minor change in present $\S 1332$ (c) which would deem corporations citizens of every state by which they had been incorporated. ALI STUDY $\$ 1301$ (b) (1), at 8; see Commentary, ALI STUdy at 60.

89 ALI STUdY § 1302 (b), (d) at 11-12; see Commentary, ALI STUdY at 68-73, 76-77. "Local establishment" is expressly defined in the proposed statute to include a busincss which renders services to persons within the state, or sells within the state with a stock of goods maintained within the state, or sells insurance or securities within the state, or produces or processes within the state. ALI STUDY $\S 1302$ (b) at 11 . It does not deprive corporations of access to a federal forum when activity within the state is minimal.

${ }^{\circ}$ Ibid.

21 ALI STUDY at 73. Although the ALI recognized that it would be logical to subject associations to the same bar as corporations, difficulty was anticipated in applying the "local establisbment" rule to large, loosely organized associations. Thus, for purposes of simplicity, the test would not apply to unincorporated associations. Ibid.

2 ALI STUdY \& 1302 (c)-(d) at 11-12.

08 The Note to $\S 1302$ (c) states the section applies to "natural" persons. ALI STUDY at 13.

os ALI STUDY $\S 1304$ (b) at 14. 
reside in different districts in the same state. ${ }^{95}$ In the event that venue is impossible under these provisions, a general clause permits an action to be brought in any district where one of the defendants resides. ${ }^{96}$

\section{The "Principal Place of Business" Test}

Determinative of the citizenship which the ALI proposes to confer on unincorporated associations is the principal place of business. While the operations of most unincorporated enterprises may be localized within one state, ascertaining the principal place of business of an association with multistate operations might present significant judicial problems. Since the ALI proposal parallels in part a 1958 amendment to the Judicial Code establishing corporate citizenship, ${ }^{97}$ the rules evolved for determining a corporation's principal place of business should also apply to unincorporated associations.

Predication of jurisdiction on a party's principal place of business was first employed in the Bankruptcy Act of 1898.98 That act permits a corporation to be adjudicated a bankrupt by a court sitting either in the corporation's state of incorporation or principal place of business, ${ }^{98}$ whereas a partnership can be so adjudicated only in the state of its principal place of business. ${ }^{100}$ Where a

"5 ALI STUDY $\$ 1304$ (a) at 14.

os See ALI STUDY $\S 1304$ (c) at 15. "This is for the purpose of avoiding the anomaly of having a case within the jurisdiction of the district courts for which there is no possible venue." Note, ALI STUDY at 16.

${ }^{07} 28$ U.S.C. $\S 1332$ (c) (1958). Note that under $\$ 1332$ (c) corporations are also deemed citizens of their state of incorporation.

The committee report accompanying the 1958 amendments to the Judicial Code stated clearly that a corporation, for diversity purposes, would be deemed to have but one principal place of business. S. REP. No. 1830, 85th Cong., 2d Sess. 5, 2 U.S. CoDE Conc. \& AD. NEws 3099, 3101-02 (1958). The cases have accepted the congressional intent that only one principal place of business be recognized. Kelly v. United States Steel Corp., 284 F.2d 850, 853 (3d Cir. 1960); see, e.g., Unger v. Del E. Webb Corp., 233 F. Supp. 713, 714 (N.D. Cal. 1964); Inland Rubber Corp. v. Triple A Tire Serv., Inc., 220 F. Supp. 490, 494 (S.D.N.Y. 1963); Kaufman v. General Ins. Co. of America, 192 F. Supp. 238, 240 (S.D. Cal. 1961); Riley v. Gulf, M. \& O.R.R., 173 F. Supp. 416, 419 (S.D. Ill. 1959).

9o Bankruptcy Act $\S 2 a(1), 30$ Stat. 544 (1898), as amended, 11 U.S.C. $\S 11$ a (1) (Supp. $V$ 1964). See Comment, $A$ Corporation's Principal Place of Business for Federal Diversity Jurisdiction, 38 N.Y.U.L. REv. 148 (1963).

${ }^{\circ 0}$ See 1 Collier, Bankruptcy ff 2.19 (14th ed. Moore 1962) thereinafter cited as COLLIER].

${ }^{200}$ Bankruptcy Act $\S 5,30$ Stat. 547 (1898), as amended, 11 U.S.C. $\S 23$ (1958). Under the traditional view, a corporation's domicile is determined by its state of incorporation, I CoLI.IER if 2.19, whereas a partnership possesses neither residence nor domicile. Id. I 2.17 . 
business had multistate contacts, convenience to the bankrupt and to its creditors came to be a major consideration in determining the principal place of business; the courts commonly looked to such factors as qualitative and quantitative loci of claims and assets, and facility of access to pertinent business records. ${ }^{101}$ In fact, it is generally recognized that the principal place of business provision in the Bankruptcy Act is treated merely as a venue preference to facilitate bankruptcy administration rather than a strict jurisdictional limitation. ${ }^{102}$

The principal place of business attracted further legislative attention in the 1958 amendment to the Judicial Code, which deemed a corporation to be a citizen of the state of its principal place of business for purposes of federal diversity jurisdiction. ${ }^{103}$ Evidently anticipating judicial problems in ascertaining the principal place of business, the Senate committee report accompanying the bill suggested reference to the cases interpreting the principal place of business provision in the Bankruptcy Act. ${ }^{104}$

However, post-1958 diversity cases interpreting the principal place of business clause have not blindly followed the bankruptcy precedent. ${ }^{105}$ Instead, two distinct analytical methods have been

${ }^{101}$ See Royal Indem. Co. v. American Bond \& Mortgage Co., 289 U.S. 165, 169 (1933); Fada of New York, Inc. v. Organization Serv. Co., 125 F.2d 120, 121 (2d Cir. 1942); Shearin v. Cortez Oil Co., 92 F.2d 855, 857 (5th Cir. 1937).

${ }_{102} 1$ CoLIIER I 2.14. Congress itself appears to have recognized this in 1952 by authorizing district courts to exercise jurisdiction in cases transferred to them under $\S 32$ of the act. 66 Stat. 420 (1952), amending $\$ 2(a)(1)$. Under $\$ \S 32(b)$-(c) which were also added by the 1952 amendment, cases may be transferred where venue is improper to any other district where it could have been brought $(\S 32 \mathrm{~b})$, regardless of the principal place of business or residence (\$ 32c). 66 Stat. 424 (1952), amending \$32. Since the act never defines where venue is proper, the use of that term in \$ 32 (b) logically refers to the provisions of $\$ 2$ (a) (1). The only sensible construction of the act is that "jurisdiction" is conferred on all district courts by $\S \S 1(10)$ and $2 a$, venue is defined in $\S 2 a(1)$, and transfer is appropriate whenever administration of the bankrupt estate would be thereby facilitated. See, e.g., In re Triton Chem. Corp., 46 F. Supp. 326 (D. Del. 1942).

${ }^{108} 28$ U.S.C. \& 1332 (c) (1958). See generally Friedenthal, New Limitations on Federal Jurisdiction, 11 STAN. L. REv. 213 (1959); Moore and Weckstein, Corporations and Diversity of Citizenship Jurisdiction: A Supreme Court Fiction Revisited, 77 HARv. L. REv. 1426 (1964); Scott, Dual Citizenship of Corporations and Their Principal Place of Business, 23 FED. B.J. 103 (1963); Weckstein, Multi-State Corporations and Diversily of Citizenship: A Field Day for Ficlions, 31 TENN. L. REv. 195 (1964); Comment, Corporations as Dual Citizens, 22 CoRP. J. 263 (1959); Comment, $A$ Corporation's Principal Place of Business for Purposes of Diversity Jurisdiction, 44 MiNN. L REv. 308 (1959). ${ }^{104}$ S. REP. No. 1830, 85th Cong., 2d Sess., 2 U.S. CODE CoNG. \& AD. NEwS 3099, 3102 (1958). See Comment, 44 MinN. L. Rev, 308, 314 (1959).

${ }^{203}$ But see Moore \& Weckstein, supra note 108, at 1439. 
developed.108 The "nerve-center" approach seeks to ascertain the locus of control of multistate operations. ${ }^{10 \pi}$ On the other hand, when most operations tend to be localized within one state, emphasis on a combination of factors, including the percentages of assets, employees, and income derived within a particular state, has been employed to provide more accurate indicia of the principal place of business. ${ }^{108}$

The problem facing the courts absent a clear preponderance of activity in one state is well illustrated by Scot Typewriter Co. $v$. Underwood Corp. ${ }^{109}$ Although Scot's domestic manufacturing facilities were centered in California, Connecticut and New Jersey, the principal place of business was determined to be New York, which was the situs of company offices from which overall direction and coordination of sales activity emanated. ${ }^{110}$ However, in Kelly $v$. United States Steel Corp., ${ }^{111}$ where corporate activities were divided between two states, the court adopted the combination approach. The preponderance of operational activity in Pennsylvania was deemed determinative of the principal place of business ${ }^{112}$ rather than the situs of policy decisions in New York, where an insignificant percentage of corporate personnel and assets were located. The Kelly approach, focusing on the state having a preponderance of operational activity, appears to be appropriate where such preponderance is relatively clear; where it is not readily apparent, the nerve-center test, centering on the locus of intracompany control, provides a convenient rule of thumb.113 Both tests, however, seem susceptible to arbitrary judicial manipulation of the various factors involved without regard to more fundamental considerations of diversity policy.

\footnotetext{
${ }^{200}$ See Comment, 38 N.Y.U.L. REv. 148 (1968).

${ }^{207}$ E.g., Egan v. American Airlines, Inc., 324 F.2d 565 (2d Cir. 1963); Sabo v. Standard Oil Co. of Ind., 295 F.2d 893 (7th Cir. 1961); Wear-Ever Aluminum, Inc. v. Sipos, 184 F. Supp. 364 (S.D.N.Y. 1960); Hughes v. United Eng'rs \& Constructors, Inc., 178 F. Supp. 895 (S.D.N.Y. 1959); Scot Typewriter Co. v. Underwood Corp., 170 F. Supp. 862 (S.D.N.Y. 1959).

${ }^{108}$ E.g., Kelly v. United States Steel Corp., 284 F.2d 850 (3d Cir. 1960); Spector v. Rex Sierra Gold Corp., 227 F. Supp. 550 (S.D.N.Y. 1964); Alpha Portland Cement Co. v. MacDonald Eng'r Co., 224 F. Supp. 714 (E.D. Pa. 1963). ${ }^{109} 170$ F. Supp. 862 (S.D.N.Y. 1959).

${ }^{110} \mathrm{Id}$. at 865 . Sales activity was expressly discounted as a determining factor in Hodges v. Georgia Kaolin Co., 207 F. Supp. 374, 376 (M.D. Ga. 1962), on the theory that sales were not the end to which the assets were devoted. 111284 F.2d 850 (3d Cir. 1960).

132 Id. at 854 .

${ }^{218}$ See, e.g., Sabo v Standard Oil Co. of Ind., 295 F.2d 893, 894-95 (7th Cir. 1961).
} 
Diversity jurisdiction is authorized by the Constitution, ${ }^{114}$ and its various policies are reflected in a fertile body of precedent and commentary. ${ }^{115}$ It must be conceded that legal scholars have not agreed on the proper policies underlying diversity jurisdiction, and it is not the purpose of this comment to resolve that issue. Nevertheless, among these policies, in view of which judicial determinations of corporate and associational citizenship should be made, prevention of possible prejudice to out-of-state litigants is apparently paramount.116 The nerve-center and combination approaches, however, frequently entail consideration of factors wholly irrelevant to prevention of local bias.117 One factor which has been considered, for example, is the state in which the corporation's federal income tax return is filed. This is deemed significant upon the circular reasoning that the Internal Revenue Code directs a corporation to file its return in the state of the principal place of business. ${ }^{118}$ Thus, a provision of law which was created purely for administrative convenience and leaves the ultimate choice to the corporation is deemed appropriate for determining access to a federal forum. Likewise, resort for guidance to the bankruptcy cases, to which the Senate report accompanying the 1958 amendment suggested reference, ${ }^{110}$ seems unwise, ${ }^{120}$ since these decisions are also prompted by questions of administrative convenience. ${ }^{121}$

Since section 1332 (c) and the ALI proposal require ascertaining

114 U.S. Const. art. III, § 2. See Moore \& Weckstein, Diversity Jurisdiction: Past, Present and Future, 43 TexAs L. REv. 1-10 (1964) and authorities cited therein.

${ }^{115}$ See, e.g., ALI STUDY at 49-58; WRIGHT, FEDERAI CoURTs 64-89 (1963); Doub, Time for Re-Evaluation: Shall We Curtail Diversity Jurisdiction?, 44 A.B.A.J. 243 (1958); Friendly, The Fistoric Basis of Diversity Jurisdiction, 41 HARv. L. REv. 483 (1928); Moore \& Weckstein, supra note 103; Moore \& Weckstein, supra note 114.

${ }^{110}$ See, e.g., Burgess v. Seligman, 107 U.S. 20, 34 (1882); Detres v. Lions Bldg. Corp., 234 F.2d 596, 597 (7th Cir. 1956); Burt v. Isthmus Dev. Co., 218 F.2d 353, 356 (5th Cir. 1955); Moore \& Weckstein, supra note 114, at $15 \mathrm{nn} .93$ \& 94; Phillips \& Christenson, The Historical and Legal Background of the Diversity Jurisdiction, 46 A.B.A.J. 959, 963 (1960).

${ }_{117}$ As such, effectuation of diversity policy may or may not result. Compare Sabo v. Standard Oil Co. of Ind., 295 F.2d 893 (7th Cir. 1961), with Hodges v. Georgia Kaolin Co., 207 F. Supp. 374 (M.D. Ga. 1962).

${ }^{118}$ INT. REv. CoDE of 1954, § 6091 (b) (2); see Scot Typewriter Co. v. Underwood Corp., 170 F. Supp. 862, 864 (S.D.N.Y. 1959).

${ }_{110}$ See report cited note 104 supra.

${ }^{120}$ E.g., Hodges v. Georgia Kaolin Co., 207 F. Supp. 374, 376 (M.D. Ga. 1962). The bankruptcy guidelines have been generally ignored by federal courts, see text accom. panying notes 98-101 supra, although bankruptcy cases have been cited along with diversity cases when the former lend support to the desired result.

121 See text accompanying notes 101.02 supra. 
only one of the numerous states in which a corporation or unincorporated association maintains a principal place of business, ${ }^{122}$ a policy-oriented analysis should subsume the principal place of business to exist in that state in which judicial prejudice to the corporation appears least likely. ${ }^{122 a}$ Under the ALI amendments, the corporation or association as a citizen could not invoke diversity jurisdiction in a federal court of that state. ${ }^{123}$ Utilization of a policyoriented approach alone, however, will not obviate the artificiality inherent in designating a single principal place of business for either a corporation or association with multistate contacts and operations.

Accordingly, where a corporation "has engaged in regular business activity to a sufficient extent to warrant'124 the inference that it will not be prejudiced by the local forum, the ALI has proposed to preclude such corporation from invoking the jurisdiction of the federal district court in that state for claims arising from the local activity. ${ }^{125}$ Moreover, the proposal has specified standards to be applied in determining when the corporation shall be deemed "locally established"; 126 these standards are carefully desigued to effectuate diversity policy. ${ }^{127}$ The rule does not apply to dealings carried on through a bona fide independent commission agent or broker. ${ }^{128}$ Furthermore, dealing through a subsidiary does not of itself constitute a local establishment. ${ }^{120}$

Since "the loose organization of many unincorporated associations into divisions, chapters, or other sub-units, would cause diffculties in applying the [local establishment] rule which are not present in the case of corporations with their more rigidly structured organizations,"130 the ALI does not impose this limitation on unin-

${ }^{122}$ See note 97 supra.

${ }_{1228}$ The underlying problem is that "verbal symbols are not adequately analyzed as to their meaning with reference to the specific problem presented for solution." Cook, The logical and Legal Bases of Conflict of Laws 215 " (1942) (emphasis in original).

${ }_{128}$ See note 88 supra and accompanying text.

124 ALI SruDY at 68-69.

${ }^{125}$ See note 89 supra and accompanying text.

${ }^{120}$ See note 89 supra.

${ }^{127}$ See ALI STUDY at 69-73. For example, mere purchasing activity "does not acquire the local identity of the sales establishment" to merit disqualification from suing in the federal court of the state where goods are bought. ALI Srudy at 7l. The proposal attempts to limit the "local establishment" bar to those situations in which a corporation would not be prejudiced by a local forum.

${ }^{128}$ ALI STUDY $\S 1302$ (b), at 11 .

${ }^{120}$ Ibid.

${ }^{280}$ ALI STUDY at 73. Although no clarification of this provision is offered in the 
corporated associations. The Study frankly admits that although it is logical to treat associations and corporations alike, the proposed draft would not bar an unincorporated association with established operations in two states from invoking diversity in one of those forums. ${ }^{131}$ It is submitted that this result accords the unincorporated association an unnecessary favored position in federal court. The local establishment rule proposed for corporations is not keyed to the form of internal organization, but rather to the nature and extent of business contacts within a jurisdiction.

\section{Effect of the ALI Proposal}

With one notable exception, ${ }^{132}$ the preponderance of scholarly opinion has favored additional restrictions on diversity jurisdiction. ${ }^{133}$ Although diversity filings increased only minimally in

Study, it is submitted that a subsidiary whose activity is significantly controlled by the parent corporation should properly result in the latter being "local established."

181 Ibid.

182 Moore \& Weckstein, supra note 114. Among other things, the authors suggest that "... the mere presence of citizens of different states on opposing sides of the con. troversy is a sufficient federal element to justify invoking federal court jurisdiction." Id. at 28. Such a rule would necessitate overruling Strawbridge v. Curtiss, 7 U.S. (8 Cranch.) 267 (1806), which is generally considered to have been based on statutory construction. See ALI Study, at 176-86; Note, 51 Nw. U.L. REv. 354 (1956).

${ }^{183}$ Those who favor restrictions note the traditional rationale that diversity juris. diction was intended only to estabhish a forum for the determination of controversies between citizens of different states which would be free from local prejudice or in. fluence. See, e.g., Burgess v. Seligman, 107 U.S. 20, 34 (1882); Detres v. Lions Bldg. Corp., 234 F.2d 596, 597 (7th Cir. 1956); Burt v. Isthmus Dev. Co., 218 F.2d 353, 356 (5th Cir. 1955); Jackson, The Supreme Court in the AMERIaAN System of Govern. MENT 36-37 (1955); Moore \& Weckstein, supra note 114, at 15; Phillips \& Christenson, supra note 116, at 963; Summers, Analysis of Factors that Infiuence Choice of Forum in Diversity Cases, 47 Iows L. REv. 933, 935-36 (1962); Warren, New Light on the History of the Federal Judiciary Act of 1789, 37 HARv. L. REv. 49, 83 (1923). But see Friendly, supra note 115, at 493-95; Yntema \& Jaffin, Preliminary Analysis of Concurrent Jurisdiction, 79 U. PA. L. REv. 869, 876 n.13 (1943), who maintain that state decisions do not reflect such prejudice. Nonetheless, Mr. Justice Frankfurter noted that "Bias against outsiders may become embedded in a judgment of a state court and yet not be sufficiently apparent to be made the basis of a federal claim." Burford v. Sun Oil Co., 819 U.S. 315, 836 (1948) (dissenting opinion).

Congress has recently acted in accordance with the desires of those who seek to limit diversity jurisdiction by extinguishing a supposed abuse, occurring under state statutes permitting suit directly against a defendant's insurer, by deeming the insurer to be a citizen of the state of the insured if the latter is not a party to the suit. P.L. 88-439, 78 Stat. 445 (1964), amending 28 U.S.C. $\$ 1332$ (c) (which changes the rule articulated in Watson v. Employers Liab. Assur. Corp., 348 U.S. 66 (1954)). This legislation was approved before enactment by the Judicial Conference of the United States. Report of the Proceenings of the Judicial Conference of the United States -1963 , at $14-15$ (1964). The Conference also approved a bill to bar from diversity jurisdiction those suits brought by fiduciaries appointed to create diversity. Id. at 16. 
$1963,{ }^{134}$ they represent the most substantial segment of federal court action $^{135}$ including eighty per cent of all jury trials. ${ }^{136}$ With the increasing caseload in federal courts, ${ }^{137}$ the ALI proposal is intended to "relieve congestion" by remitting approximately half of the general diversity cases to the state courts. ${ }^{138}$ Thus, the proposal to prohibit invocation of diversity jurisdiction by a citizen of the state in which an action is brought ${ }^{139}$ is viewed as excluding 43.8 per cent of all diversity actions. ${ }^{140}$ The purpose of this comment, however, is to evaluate the effect upon the diversity caseload of the limited proposal to designate unincorporated associations as "citizens" for diversity purposes.

\section{Statistical Data}

At first glance the sheer number of unincorporated associations in this country would seem to support the contention that facilitating access to diversity jurisdiction in cases involving such associations would be tantamount to opening Pandora's box. By 1958 there were 264,385 unincorporated associations engaged in retail trade, ${ }^{141}$ 38,379 in wholesaling enterprises, ${ }^{142} 97,453$ in "selected services,"143

${ }^{184}$ The increase in diversity filings was only 3.4\% over 1962 . Cases to which the United States was a party increased $5.4 \%$ and fereral question filings increased $16.4 \%$ during the same period. AnNual Report of THE DiRector of the UNited States CourTs-1963 Table F, at 123 (1964).

${ }^{185} 58.8 \%$ of diversity filings required some court action, $18.5 \%$ reaching trial. $I d$. at 125 .

$180 \mathrm{Id}$. at 126.

${ }^{137} 63,630$ cases were filed in the federal district courts in fiscal 1963. REPORTS of The Proceedings of The Judicial Conference of The United States-1963 at 58 (1964). Excluding private anti-trust suits against electrical equipment companies and local cases in the District of Columbia, the number is reduced to 56,928 , which represents a $7.7 \%$ increase in filings over fiscal 1962. ANNUAL REPORT OF THE DIRECTOR OF THE UNITED STATES Courrs-1963 Table F at 123 (1964).

Cases pending in the courts of appeals increased 14\% during fiscal 1963 despite a $20 \%$ increase in cases terminated. Id. at 111 .

${ }^{188}$ ALI STUDY at 5.

180 AI.I STUDY $\S 1302$ (a) at 11.

${ }^{110}$ ALI STUDY at $68 \mathrm{n} .11$. This figure represents the percentage of diversity cases in 1963 which were instituted by an "in-state" plaintiff. If these plaintiffs were precluded by $\S 1302$ (a), however, it is reasonable to assume that many would have still invoked diversity jurisdiction in the defendants' state.

1411958 Census of Business, Retarl Trade Summary Statistics Table N at 17 (1961). This figure represents the sum of partnerships and "other." Apart from these two categories, other legal forms listed are individual proprietorships $(1,240,171)$, corporations $(277,805)$, and cooperatives $(5,964)$. Partnerships and "cooperatives and other" accounted for $\$ 30.5$ billion of retail sales while corporations liad $\$ 63$ billion in retail sales. $I d$. Table $\mathrm{P}$, at 18 .

16231958 Census of Business, Wholesale Trade Summary Statisttcs Table 5A at 5.2 (1961). This figure represents the sum of partnerships and "other." Other legal 
10,310 engaged in the mineral industries, ${ }^{144}$ and 44,157 in manufacturing ${ }^{145}$-a total of 454,684 unincorporated enterprises exclusive of labor unions, fraternal organizations, and religious and charitable groups. Other available data indicates, however, that with respect to the first three classifications above, 98 percent of the total unincorporated associations were partnerships, and the number of "active proprietors" of such partnerships averaged about two for every one. ${ }^{145 \mathrm{a}}$ Although this does not indicate the number of non-participating partners; it seems reasonable to presume that many of these partnerships have only two or three partners living within the same state. As such, the ability of these associations to sue and be sued in the federal court would not be enhanced by the ALI proposal.

In order to gauge accurately the extent to which enactment of the ALI proposal would increase the diversity caseload, it would be necessary to determine how many unincorporated associations have members who are citizens or residents of states other than those of the principal places of business of the organizations to which they belong. However, available data is of little assistance in this regard. Statistics disclose only that in 1958 almost nine million persons worked in a county other than that in which they resided. ${ }^{148}$ This

forms listed are individual proprietorships (78,428), corporations (162,184), and cooperatives $(7,005)$. Ibid. Respective percentages of sales are indicated id. Table $\mathrm{N}$, at 19.

248 51958 Census of Business, Selected Services Summary Statistics Table 5A at 5-2 (1961). This figure represents the sum of partnerships and "other." Other legal forms listed include individual proprietorships (786,371), corporations $(90,527)$, and cooperatives (899). Ibid. Individual proprietorships received $31.8 \%$ of receipts, cor. porations $55.4 \%$, and partnerships $12.2 \%$. Id. Tahle $\mathbf{T}$ at 21 . Other legal forms, including cooperatives, received $0.6 \%$ of total receipts. Id. Table $S$ at 20.

1*4 1958 Census of Mineral Industries Summary AND INDUSTRy Statistics 3-2, at 3-3 (1961). This figure represents the sum of partnerships and "other" which was comprised primarily of joint ventures. Id. at $3-2 \mathrm{n} .2$. These figures reflect "type of ownership or control." Id. at 3-2. Other legal forms listed include individual proprietorships $(12,222)$, corporations $(13,589)$, and cooperatives $(97)$.

${ }_{140} 1958$ Census of Manufactures Summary Statistics Table 1, at 3-2 (1961). This figure represents the sum of partnerships and "other," which includes coopera. tives. Other legal forms listed include individual proprietorships $(91,276)$ and corporations (162,749). Ibid.

1482 There were 259,352 retail trade partnerships with 535,326 "active proprietors," 37,601 wholesale trade partnerships with 80,599 "active proprietors," and 96,509 selected services partnerships with 198,494 "active proprietors." 11958 CENSUS of Business Retail Trade Summary Statistics Table 5A at 5-2 (1961); 31958 Census of Business Wholesale Trade Summary Statistics Table 5A at 5-2 (1961); 5 1958 Census OF Business Selected Services Table 5A at 5-2 (1961).

140 11960 Census of Population Characteristics of the Population Pt. 1, United States Summary TABle 135, at 1-284 (1964). This figure constitutes 13.9\%\% of the entire United States population. Ibid. 
data is not computed on a statewide basis; nor does the census indicate whether such persons were affiliated with corporations or unincorporated associations.

It is also noteworthy that one hundred eighty-one national and international labor unions, with a total membership in excess of seventeen million persons, ${ }^{1+i}$ are headquartered in the United States. ${ }^{148}$ Since all but fifteen of such unions have more than 1,000 members, ${ }^{149}$ it is reasonable to assume a high incidence of multistate membership among them.

While quantitatively impressive, these statistics furnish no cause for alarm at the ALI proposal. At present there is no apparent basis for ascertaining either the number of unincorporated associations with multistate membership or the number of association members who are citizens of different states than their associations' principal places of business. Moreover, even assuming that enactment of the ALI proposal would significantly increase diversity access by and against unincorporated associations, it seems impossible to determine the extent to which increased access would entail increased utilization of federal forums. ${ }^{150}$

\section{Juridical Capacity Under State Law}

Apart from the inconclusiveness of available statistics, it is fundamental to note that enactment of the ALI proposal regarding unincorporated associations would affect the diversity caseload only in states where an association is empowered by state law to sue and be sued in its common name. ${ }^{151}$ The objective of the Institute is simply "to parallel the treatment accorded to associations under State law without the existing restraints of the complete diversity

\footnotetext{
${ }^{167}$ Statistical Abstract of the United States No. 239, at 247. This figure includes Canadian members $(1,044,000)$ of labor unions with United States headquarters and excludes members of "noninterstate independent or unaffliated unions." Ibid.

${ }^{148} \mathrm{Id}$. No. 330, at 248 (1964). This figure excludes what is termed "noninterstate independent or unaffliated unions." Ibid.

${ }^{160}$ Ibid.

${ }^{150}$ See Summers, supra note 133. Note also that under the ALI proposal a plaintiff would be precluded from suing in any judicial district of a state in which he was a citizen. See note 88 supra and accompanying text. Thus, convenience alone may force suits by or against unincorporated associations to state courts.

${ }^{251}$ The ALl proposal would apply only to "a partnership or other unincorporated association capable of suing or being sued in its common name in the State in which an action is brought. " ALl STUDY $\S 1301$ (b) (2), at 8; see Commentary, ALI STUdY at 62 .

Transfer under present 28 U.S.C. $\$ 1404$ (1958) could result in an increase in the caseload in a state which did not allow common name suits.
} 
requirement."152 Associational capacity to sue and be sued would continue to be governed by Federal Rule 17 (b), which adopts state law concerning capacity in diversity cases. ${ }^{163}$

It is clear that the diversity caseload would be totally unaffected in at least eight states which still adhere to the common law aggregate theory, ${ }^{154}$ under which unincorporated associations can neither sue nor be sued in their common names. ${ }^{155}$ At the other extreme, at least nine states fully recognize the capacity of associations to sue and defend in the associational name. ${ }^{156}$ It seems reasonable to assume that even where common-name provisions are contained in rules of court rather than in statutes, ${ }^{157}$ they will be characterized as "substantive" and will not be abrogated by a technical application of the Erie doctrine. 158

Beyond these poles of clarity lie several statutory species under which the effect of the ALI proposal is uncertain. Some states, for example, purport to deny entity status to associations, ${ }^{150}$ yet permit

182 ALI STUDY at 62.

${ }^{253}$ The capacity of a partnership or other unincorporated association to sue or be sued "shall be determined by the law of the state in which the district court is held" except for purposes of federal question jurisdiction. FeD. R. Civ. P. 17 (b). * See ALI STUDY at 62.

284 See Lafayette Chapter of Property Owners Ass'n v. City of Lafayette, 129 Ind. App. 425, 430-81, 157 N.E.2d 287, 290-91 (1959); Lamm v. Stuen, 226 Iowa 622, 626, 284 N.W. 465, 467 (1939); Diamond Block Coal Co. v. United Mine Workers, 188 Ky. 477, 490-91, 222 S.W. 1079, 1085 (1920); Maria Konopnicka Society v. Maria Konopnicka Society, 831 Mass. 565, 568, 120 N.E.2d 769, 771 (1954) (non-legal entity cannot be party to litigation); Varnado v. Whitney, 166 Miss. 663, 666-67, 147 So. 479,480 (1933); Forest City Mfg. Co. v. International Ladies Garment Workers' Union, 233 Mo. App. 985, 111 S.W.2d 934 (1938). See generally Forkosch, The Legal States and Suability of Labor Organizations, 28 TEMP. L.Q. 1 (1954) (summary of law in each state).

${ }^{158}$ E.g., Milam v. Settle, 127 W. Va. 271, 278, 32 S.E.2d 269, 272 (1944); Lamm v. Stoen, 226 Iowa 622, 626, 284 N.W. 465, 467 (1939). See United Mine Workers v. Coronado Coal Co., 259 U.S. 344, 385 (1922); Kaplan, Suits Against Unincorporated Associations Under the Federal Rules of Civil Procedure, 53 MICH. L. REv. 945 (1955). See also Annot, 149 A.L.R. 508 (1944).

${ }^{150}$ Alaska R. Crv. Proc. 17 (c); Colo. Rev. Stat. Ann., R. Crv. Proc. 17b (1958); Conn. Gen. Stat. ANn. \$ 52.76 (1960); MD. ANN. Code art. 23, § 138 (1957); Minn. Stat. ANN. § 540.151 (Supp. 1964); N.J. STAT. ANN. § 2A:64-1 (1952) (seven or more members); PA. Rules Civ. Proc. 2151-53 (excluding partnerships and joint stock companies); VT. StaT. ANN. tit. 12, § 814 (Supp. 1963); VA. Code ANN. § 8-66 (Supp. 1964).

${ }^{157}$ In at least one instance, the court rule is derived from a former statute. Compare Repealed Mich. Comp. Laws \$ 612.12 (1948), and Mich. Gen. Cr. Rules 201.3 (3). The capacity to sue in a common name would seem to be substantive and it frequently is material in determining sources of satisfaction of the judgment. On the related problem of entity-individual liability see Comment, 68 YALE L.J. 1182 (1959).

${ }_{188} 304$ U.S. 64 (1938). For a discussion of problems arising from class actions in diversity cases when the state court will not hear class actions, but only "entity" actions, see Comment, 68 YALE L.J. 1182, 1192 (1959).

${ }^{180}$ Wilson v. Airline Coal Co., 215 Iowa 855, 857, 246 N.W. 753, 754.55 (1933) (labor 
suits by or against unincorporated enterprises through class actions ${ }^{160}$ or suits against representative association officers. ${ }^{161}$ It is not clear that such statutes could or would be construed to allow suits in the associational name. Similarly, other statutes do not expressly sanction suits by associations in the common name, yet specify that process shall be served on association officers in actions ${ }^{162}$ or class actions $^{162 a}$ against the enterprise. Still other states expressly permit common-name actions only against unincorporated associations. ${ }^{103}$ Finally, analysis of statutes which allow suits by or against "business associations" requires examination of case law to determine what form or size of association is within the statute. ${ }^{164}$

It is clear in the ALI's proposal that where an unincorporated association is vested with juridical capacity under state law, the ability to sue and be sued as a citizen prevents invocation of diversity jurisdiction by means of the federal class action procedure. ${ }^{165}$ The

union); Lafayette Chapter of Property Owners Ass'n v. City of Lafayette, 129 Ind. App. 425, 430.3I, 157 N.E.2d 287, 290-9I (1959).

${ }^{100}$ Iowa R. Civ. Proc. 42. See Ore. Rev. Stat. $\$ 13.17$ (Supp. 1963); Wash. Rev. CODE $\$ 4.08 .070$ (1952).

${ }_{101}$ E.g., IND. ANN. STaT. $\$ 2-220$ (Supp. 1964). See Shisser v. Romine, 102 Ind. App. 25, 31, 200 N.E. 731, 733-34 (1936); N.Y. GEN. Ass'NS LAW $\$ \$ 12-13$ (1942, Supp. 1964) (proceeding by or against an unincorporated association may be maintained by its president or treasurer).

${ }^{102}$ E.g., R.I. GEN. LAws ANN. $\$ \S 9-2-10$ to -11 (1956) (service of process statute).

${ }^{1020}$ E.g., N.H. REv. STAT. ANN. $\$ 510: 13$ (1955) (class action type of statute which speaks only in terms of service on officers). An association is not a distinct entity in New Hampshire. Sunapee Dam Corp. v. Alexander, 87 N.H. 397, 181 Atl. 120, 123 (1935).

${ }^{108}$ E.g., Ala. Code tit. 7, $\S 14 I-43$ (1960); Cal. Civ. Proc. Code $\$ 388 ;$ La. Rev. Stat. § 13:347I (22) (1950); N.C. GEN. STAT. § 1-97 (6) (1953); S.C. CODE ANN. § 10-215 (I962); S.D. Code § 33.0408 (Supp. 1960); TENN. CODE ANN. \$ 20-223 (Supp. 1964). In at least two of these states, an unincorporated association has been permitted to sue in its common name despite the statute. See Daniels v. Sanitarium Ass'n, Inc, $59 \mathrm{Cal} .2 \mathrm{~d} 625$, 381 P.2d 652, 30 Cal. Rptr. 828 (1963), 37 So. CAL. L. REv. 130 (1964); Ionic Lodge v. Ionic Masons, 232 N.C. 252, 59 S.E.2d 829 (1950).

106 E.g., CAt. Civ. Proc. CODE $\$ 388$, held to include labor unions in Oil Workers Int'l Union v. Superior Court, 103 Cal. App. 2d 512, 230 P.2d 71 (Dist. Ct. App. 1951); Del. CODE ANN. tit. 10, $\$ 3904$ (1953) (statute excludes ordinary partnerships); IdAHo CODE ANN. § 5-323 (1947); N.J. STAT. ANN. § 2A:64-I (195I) (statute applies only to associations with seven or more members); N.J. STAT. ANN. $\S 2 A: 64-6$ (1951) (nonprofit organizations cannot be sued in common name), interpreted in Newark Int'l Baseball Club, Inc. v. Theaterical Managers, Agents \& Treasurers Union, 125 N.J. Eq. 575,7 A.2d 170 (Ch. 1939) that the non-profit exception did not extend to labor unions.

${ }^{105}$ Section 1301 (b) (2) of the Draft would allow the class action under the Federal Rules of Civil Procedure in those states which do not allow common name suits. See note 85 supra. One policy underlying the class action provisions of the federal rules is to allow suits involving unincorporated associations to be litigated in the federal cuurts. Moore. Federal Rules of Civil Proredure Some Problems Raised by 
net result of this may be to reduce the amount of diversity cases involving such associations by obviating the ability to select certain members as "representative" of the class. ${ }^{100}$ Where juridical capacity is lacking, however, the proposal would appear to permit federal class actions, ${ }^{167}$ thus perpetuating a questionable means of creating diversity jurisdiction.

\section{Venue}

The ALI proposal to treat unincorporated associations as residents of the districts of their principal places of business for venue purposes would have no effect on the federal caseload in those courts already employing such an approach. ${ }^{168}$ Where section 1391 (c) is presently interpreted to apply to associations, ${ }^{168}$ the proposal would have a restrictive effect on venue choices in that the alternatives available under that section would be replaced by a single venue locus. It would not, however, preclude any cases from federal court once diversity jurisdiction was established. ${ }^{170}$ On the other hand, the proposal would increase the caseload in the majority of jurisdictions in which residence for venue purposes is presently conditioned on the residence of every member of the association, ${ }^{171}$ because the ALI proposal establishes an appropriate venue whenever diversity jurisdiction exists. ${ }^{172}$

Laying venue in the state of the association's principal place of business would probably accord in most cases with considerations of mutual litigative convenience and thus subserve the policy under-

the Preliminary Draft, 25 Geo. L.J. 551, $570-76$ (1937); Comment, 68 YALE L.J. 1182, 1192 \& n.51 (1959). See Kaplan, supra note 155, at 954-61.

${ }^{100}$ See text accompanying notes $12-22$ supra.

${ }_{107}$ See ALI STudy $\S 1301$ (b) (2), at 8, Commentary, ALI STUdy at 62.

${ }^{208}$ See notes 76-77 supra and accompanying text.

${ }^{102}$ See note 78 supra and accompanying text.

170 Under the ALI proposal, residence for venue purposes of both corporations and unincorporated associations is identical to state citizenship for diversity purposes. Compare ALI STUdy $\$ 1304$ (b) at 14, and ALI STudy $\S 1301$ (b) (1)- (2), at 8. Plaintiffs would he precluded from invoking diversity jurisdiction in the state of their citizenship. See ALI STUDY $\S 1302$ (a) at 11 ; note 88 supra. Thus, venue is proper only in districts or states wherein the cause of action arose or all defendants reside. ALI STUDY $\S$ 1304 (a) at 14. An escape clause, however, permits venue to be laid in any district in which one of the defendants resides if a proper venue would otherwise be impossible. ALI STudy $\S 1804$ (c) at 15 . The purpose of this section is to assure a proper venue for every case in which there is diversity of citizenship. Commentary, ALI STudy at 83. ${ }^{177}$ See notes $72-75$ supra and accompanying text.

19 See notes 96 \& 170 supra. 
lying all federal venue provisions. One factor tending to limit the anticipated caseload effect is the ALI proposal to eliminate plaintiff residence as an appropriate locus for venue. Furthermore, providing a single basis for both jurisdiction and venue would enable conservation of judicial time and effort.

p. b. a.

j. j. $b$.

w. b. s., jr. 